\title{
Bee species recorded between 1992 and 2017 from green roofs in Asia, Europe, and North America, with key characteristics and open research questions
}

\author{
Michaela M. Hofmann, Susanne S. Renner \\ Systematic Botany and Mycology, Faculty of Biology, University of Munich (LMU), 80638, Munich, Germany
}

Received 15 July 2017 - Revised 19 October 2017 - Accepted 27 October 2017

\begin{abstract}
Green roofs, which have become mandatory on new flat-topped buildings in many cities, increase habitat connectivity for wildlife and have contributed to a boom in urban beekeeping. The ecological benefits or risks of green roofs for wild bees (bee species other than the domesticated honey bee, Apis mellifera), however, have not been comprehensively analyzed. We therefore reviewed studies on insects caught on green roofs in Asia, Europe, or North America between 1992 and early 2017 and extracted information on wild bees. The resulting species list includes 236 Apidae identified in 35 studies, with thermophilic species probably overrepresented because roofs provide warm and dry habitats. The percentage of cavity-nesting bees on roofs is higher than that on nearby ground, while the percentage of pollen specialists is lower. Data are almost completely lacking on the reproductive success of bees on green roofs, the effect of roof age on bee diversity, and the genetic or demographic benefits of increased habitat connectivity. Our list of the bee species so far reported on green roofs will help in the selection and implementation of suitable soils, nesting aids, and plantings.
\end{abstract}

\section{Bees / Cavity-nesting species / Ground-nesting species / Species diversity / Urban habitats}

\section{INTRODUCTION}

The past 20 years have seen a dramatic increase in research on green roofs (reviewed in Bowler et al. 2010 and Blank et al. 2013), which are now mandatory on flat-topped buildings in Switzerland and a few other European countries and supported by incentives in the USA (Brenneisen 2006; Stutz 2010). Although there are different types of green roofs, one can generally distinguish between intensive and extensive roof greening. Intensive green roofs usually have a soil layer of at least $15 \mathrm{~cm}$ and sometimes up to

Electronic supplementary material The online version of this article (https://doi.org/10.1007/s13592-017-0555-x) contains supplementary material, which is available to authorized users.

Corresponding author: M. Hofmann, michaelahofmann181@gmx.de;

S. Renner, renner@1mu.de

Manuscript editor: Stan Schneider
$60 \mathrm{~cm}$ or more (Mann 1994), while extensive green roofs have only a thin layer of soil $(5-15 \mathrm{~cm})$, supporting mostly mosses, herbs, succulents, and grasses (Gedge and Kadas 2005). Roofs with shallow soil layers are a difficult growing environment for plants because of moisture stress, severe drought, and full exposure to sun and wind (Schneider and Riedmiller 1992; Dunnett and Kingsbury 2008). On the other hand, extensive roofs require minimal maintenance and can be self-sustaining.

Ecosystem services from green roofs include storm-water management (Getter and Rowe 2008; Berndtsson 2010), moderation of the urban heat island effect (Takebayashi and Moriyama 2007; Tabares-Velasco et al. 2012), lower building temperatures (Oberndorfer et al. 2007), and a role as urban wildlife habitat (for reviews, see Fernandez-Canero and Gonzalez-Redondo 2010, Williams et al. 2014, and Gonsalves 2016). An important aspect for the latter role is that green roofs are undisturbed by humans during most of the year, making them quiet 
habitats with low pesticide loads (Hui and Chan 2011). They also increase habitat connectivity for certain arthropods (Braaker et al. 2014).

Of the many arthropods living on green roofs, bees stand out because of their role as pollinators and because urban beekeepers tend to find beekeeping "restorative and empowering" (Moore and Cost 2013). While urban beekeeping has led to an increase of the density of honey bees in cities, the past 50 years have seen a decline in the abundance of wild bee species, attributed mostly to habitat loss and pesticides (Goulson et al. 2008), although hard data on change in bee abundances in urban spaces over time are scarce. Wild bees, most of which are solitary bees, are expected to benefit from the newly created habitat on green roofs because they may be able to forage both on the ground and on green roofs, and thermophilic species might also find nesting opportunities on green roofs. Surprisingly, however, the effects of green roofs on the diversity and abundance of wild bees in cities have received little attention despite repeated calls for bee-targeted green roof research (Zurbuchen and Müller 2012; Witt 2016). We here provide the first list of bee species recorded from green roofs, summarize key ecological traits of these bees, and point to important open questions about the role of green roofs as habitat for solitary bees.

\section{MATERIALS AND METHODS}

We searched relevant keywords, such as "green roof" (or "living roof," or "Gründach"), and "bee" (or hymenoptera or Wildbienen), using the search engines Web of Science (http://www.isiknowledge. com), ScienceDirect (http://www.sciencedirect. com), Google Scholar (https://scholar.google.de), and Google (https://www.google.de). We also included online-only journals, B.Sc., M.Sc., and diploma reports, and doctoral theses. Abstracts were checked to see whether a study covered wild bees on green roofs, and studies exclusively dealing with urban beekeeping were excluded because honeybees are a managed species.

Each found study was scanned for the following information: (i) Where and when was the study conducted? (ii) How many roofs were investigated and which sampling technique was used? (iii)
Which roof type (extensive or intensive) was investigated and were there non-roof reference areas? (iv) Which taxa were found? Were the specimens identified to species level? Results were tabulated and a species list was created as a basis for future work on green-roof-occurring species.

\section{RESULTS AND DISCUSSION}

Based on the criteria laid out above, we found 35 studies dealing, at least partially, with wild bees on green roofs (Table S1, Supplementary Material). Compared to the 300 peer-reviewed studies about green roofs available by 2013 (Blank et al. 2013; a number supported by our search) and the large numbers of hits when searching for "green roof" on ScienceDirect ( $n=1982$, accessed 1 March 2017) or the Web of Science ( $n=916$, accessed 1 March 2017), a number of just 35 studies mentioning wild bees on green roofs is low. Almost $40 \%$ of these 300 publications on green roofs deal with engineering aspects, and another $37 \%$ with general aspects of the environment and ecology. Only $3 \%$ are assigned to the ISI category biodiversity conservation (Blank et al. 2013), a category that encompasses studies on plants, birds, beetles, collembolans, soil arthropods, spiders, and other invertebrates (Williams et al. 2014). Of the 35 studies, eight fully focus on wild bees (Brenneisen 2005; Colla et al. 2009; Tonietto et al. 2011; Ksiazek et al. 2012, 2014; Kratschmer 2015; MacIvor et al. 2015; Walker 2016); the remaining 27 included hymenopterans other than bees. The longest species lists contain 77 (Brenneisen 2006), 79 (Colla et al. 2009), 91 (Kratschmer 2015), or 126 species (Braaker et al. 2014), showing that green roofs are indeed an important habitat for wild bees.

Especially thermophilic species (not only bees but also other arthropods) adapted to living under dry conditions have been reported from green roofs, including a few rare species (Jones 2002; Kadas 2006; MacIvor and Lundholm 2011; Kratschmer 2015). Generally, intensive green roofs, have a higher bee diversity and abundance than extensive green roofs (Brenneisen 2006; Madre et al. 2013; Kratschmer 2015; Witt 2016), and unsurprisingly green roofs with a higher 
number of plant species tend to have a higher number of bee species (Köhler 2014).

So far, 236 species have been recorded on green roofs (Table S2, Supplementary Material), with several additional species present, but not identified to species level (at least $n=13$ ). Several studies, unfortunately, mention species lists in the text, but fail to make them available (Mann 1996a, b; Köhler 2014; Braaker et al. 2014, 2017). Of the 236 species, 151 are from Europe and 72 from North America. Eleven species were found both in Europe and America. The only Asian study of bees on green roofs reported three species, including the honey bee (Nagase and Nomura 2014). For Africa and Australia, no studies about wild bees on green roofs were found.

Only three studies provide data on bee foraging behavior (Mann 1994; Kratschmer 2015; Witt 2016). All showed that oligolectic species are underrepresented on green roofs. While it is not known how many of the estimated 20,000 species of wild bees worldwide are oligolectic (Michener 2007), green roofs appear to be used by few oligolectic bees: Thus, $11 \%$ of the species found on green roofs in Vienna, Austria, and Hannover, Germany, were oligolectic (Kratschmer 2015; Witt 2016) and 4\% of those on a roof in Böblingen, Germany (Mann 1994), while the number of oligolectic species in the Austrian, German, and Swiss bee faunas overall is ca. 30\% (Zurbuchen and Müller, 2012: p. 26), which for Germany would be 193 (Schmidt et al. 2015). These findings fit with a noted decrease in foraging specialists among insect species in urban compared to rural areas (Hernandez et al. 2009).

Another "green roof bee fauna" characteristic is the high proportion of cavity-nesting compared to ground-nesting species. Of the ca. 580 wild bee species in Germany, Liechtenstein, Austria, and Switzerland (Schmidt et al. 2015), some 50\% breed in the ground, $23 \%$ above ground, and $25 \%$ are parasites, but even in Europe, the nesting sites of at least 23 species are unknown (Zurbuchen and Müller, 2012: p. 57). On green roofs in Vienna, $31 \%$ of the wild bee species nested above ground (Kratschmer 2015) and in Chicago 30 to $35 \%$ (Tonietto et al. 2011; Ksiazek et al. 2014). By comparison, $40 \%$ of the green roof species in $\mathrm{Vi}$ enna nested in the ground (Kratschmer 2015) and
60 to $70 \%$ of those in Chicago (Ksiazek et al. 2014; Tonietto et al. 2011). The latter high percentages may be partly a collecting artifact, since groundnesting species are more likely to be caught in pan traps, which was the method used in these studies. Artificial nesting aids on green roofs may increase the species diversity of cavity-nesting bees, but if they are installed on the roofs of high raises, reproductive success, measured as finished brood cells, may be low (MacIvor 2016). Artificial nesting sites for ground-nesting bees, consisting of sand and earth layers with a thickness of $20 \mathrm{~cm}$, can be sufficient for bees to nest (Brenneisen et al. 2014).

Regarding body size, one would expect relatively many large species on green roofs, since they have larger foraging distances and therefore may detect vertically distant foraging grounds more readily than small bee species (Greenleaf et al. 2007). Indeed, MacIvor et al. (2015) found more medium and large than small bees on green roofs in Toronto, Canada, but small bees dominated the species spectrum on roofs in Chicago and Vienna (Ksiazek et al. 2012; Kratschmer 2015). These different results may be partly explained by these authors' different collecting methods, namely netting vs. pan trapping. Small bees were especially frequent, when the soil depth exceeded $20 \mathrm{~cm}$ (Kratschmer 2015). Further studies are required to understand the correlation of green-roof nesting and bee body size, itself related to foraging distance, which is of prime importance in the successful reproduction of bees nesting on roofs.

Few of the plants that do well on green roofs are good nectar and pollen sources for wild bees, most important among them probably the species of Sedum (MacIvor et al. 2015), but the number of plant species on green roofs is extremely low compared to that on ground-level habitats (MacIvor and Lundholm 2011; Tonietto et al. 2011; Ksiazek et al. 2012, 2014; Braaker et al. 2014, 2017), and in spite of "habitat connectivity" (enhancing both gene flow and numbers of individuals) being among the most often quoted benefits of green roofs, only a single study so far has provided data supporting this notion (Braaker et al. 2014, 2017).

Table I summarizes expectations and findings about the species diversity and life history types of bees on green roofs. Based on the available data (Table I; Supplementary Material: Tables S1, S2), 
Table I. Trends observed in bee size, diet, and nesting habitat when comparing bees from green roofs and nearby ground-level habitats

Green roof features

Predicted consequences for bee

Results from the 35 studies reviewed here

diversity

Green roofs are hot and dry habitats.

Intensive roofs have higher plant diversity than extensive roofs.

\section{Reduced plant species numbers compared to ground-level habitats \\ Extensive green roofs have a thin soil layer.}

Green roofs are planted on buildings, thus more or less high above ground.
Thermophilic species predominate on green roofs.

Higher plant diversity can support higher bee diversity.

Insufficient food supply for specialist bees

Ground-nesting species, especially larger species with deep nests, cannot breed on green roofs.

Vertical isolation from ground habitats is especially hard to overcome for small bee species.
Increased proportion of thermophilic species (Jones 2002; Kadas 2006; MacIvor and Lundholm 2011; Kratschmer 2015)

Higher abundances and species numbers on intensive, biodiverse green roofs (Köhler 2014; Brenneisen 2006; Madre et al. 2013; Kratschmer 2015; Witt 2016)

Oligolectic bee species are underrepresented on green roofs (Mann 1994; Kratschmer 2015; Witt 2016).

Increased proportion of cavity-nesting species compared to ground-nesting species (Tonietto et al. 2011; Ksiazek et al. 2014, Kratschmer 2015)

Large and medium-sized species are some times overrepresented (MacIvor et al. 2015) but not always (Ksiazek et al. 2012; Kratschmer 2015). more work is needed to better understand the potential of green roofs as an urban bee habitat. Thus, there are still no solid data on how readily wild (solitary and semi-social) bees change between roofs and ground-level habitats for foraging or nesting or whether they ever travel between different roofs (i.e., whether roofs connect habitats). Marking experiments are urgently required, such as have long been successfully applied in studies of other insects (Walker and Wineriter 1981; for reviews see Hagler and Jackson 2001). There are also only anecdotal observations of roof-breeding bees (e.g., Kratschmer 2015), rather than hard data on the breeding success or failure of bees that have accepted the nesting aids installed on green roofs. If green roofs are intended as an alternative habitat for bees, it is crucial to understand how well they can reproduce there. Otherwise, the risk that green roofs may become an "ecological trap," that is, habitats that cannot sustain reproducing populations (Donovan and Thompson 2001), is high, meaning that species accept green roofs for nesting, but then fail to rear their brood. This is the case in some groundbreeding birds, such as lapwings (Vanellus vanellus), that built nests on green roofs, but with low chick survival due to insufficient food and water on the roofs (Baumann 2006).

Another open question is the speed of colonization by wild bees of newly established green roofs and their development as bee habitat over time. Studies on this topic so far have focused on plants (Köhler 2006; Emilsson 2008; Nagase and Nomura 2014; Deng and Jim 2016; Lundholm 2016; but see Kadas 2006).

\section{CONCLUSIONS}

Despite public awareness of the importance of wild bees as pollinators of most flowering plants and the current enthusiasm for urban beekeeping (Moore and Kosut 2013), little is known about the role of green roofs as a habitat for wild bees, in terms of both foraging and for successful nesting. Small-scale local conditions determine the nestsite selection by bees in general as well as in urban areas (Everaars et al. 2011), and artificial nesting aids matching the preferences of specific bee species could promote bee reproduction on green roofs. Our list of the 236 species of wild bees that have so far been reported on green roofs (Table S2, Supplementary Material) will help in 
the selection and implementation of suitable soils, cavity-providing structures, or plants addressed to species managing to breed on green roofs. The promise of green roofs as urban bee habitat will only be fulfilled with more research on wild bees' requirements for successful reproduction.

\section{CONTRIBUTIONS}

MH compiled the data and wrote the first draft; $\mathrm{MH}$ and SSR co-wrote the final draft. Both authors read and approved the final manuscript.

Espèces d'abeilles inventoriées entre 1992 et 2017 sur les toits végétalisés en Asie, Europe et Amérique du Nord, avec leurs principales caractéristiques et des questions de recherche ouvertes

Abeilles / espèces nichant dans des cavités / espèces nichant au sol / diversité des espèces / habitats urbains

Bienenarten, die zwischen 1992 und 2017 auf Gründächern in Asien, Europa und Nordamerika nachgewiesen wurden, einschließlich von Schlüsselmerkmalen und bisher ungeklärten Forschungsfragen

Solitärbienen / höhlenbrütende Arten / bodenbrütende Arten / Artenvielfalt / urbane Habitate

\section{REFERENCES}

Baumann, N. (2006) Ground-nesting birds on green roofs in Switzerland: preliminary observations. Urban Habitats $4,37-50$.

Berndtsson, J.C. (2010) Green roof performance towards management of runoff water quantity and quality: A review. Ecol. Eng. 36, 351-360.

Blank, L., Vasl, A., Levy, S., Grant, G., Kadas, G., Dafni, A., Blaustein, L. (2013) Directions in green roof research: A bibliometric study. Build. Environ. 66, 23-28.

Bowler, D.E., Buyung-Ali, L., Knight, T.M., Pullin, A.S. (2010) Urban greening to cool towns and cities: A systematic review of the empirical evidence. Landsc. Urban Planning 97, 147-155.

Braaker, S., Ghazoul, J., Obrist, M.K., Moretti, M. (2014) Habitat connectivity shapes urban arthropod communities: the key role of green roofs. Ecology 95, 1010-1021.

Braaker, S., Obrist, M.K., Ghazoul, J., Moretti, M. (2017) Habitat connectivity and local conditions shape taxonomic and functional diversity of arthropods on green roofs. J. Anim. Ecol. 86 : 521-531.
Brenneisen, S. (2005) The natural roof (NADA). Research project report of the use of extensive green roofs by wild bees. University of Wädenswil, Wädenswil, Switzerland.

Brenneisen, S. (2006) Space for urban wildlife: designing green roofs as habitats in Switzerland. Urban Habitats 4, 27-36.

Brenneisen, S., Käppeli, S., Schneider, R. (2014) Förderung gefährdeter Wildbienen auf Flachdächern Forschungsprojekt im Mandat für Pro Natura. https://www.zhaw.ch/no_cache/en/research/people-publications-projects/detail-view-project/projekt/1835/ (accessed April 10, 2017).

Coffman, R.R., Waite, T. (2011) Vegetated roofs as reconciled habitats: rapid assays beyond mere species counts. Urban Habitats 6 (electronic journal). http://www. urbanhabitats.org/v06n01/vegetatedroofs_full.html

Colla, S.R., Willis, E., Packer, L. (2009) Can green roofs provide habitat for urban bees (Hymenoptera: Apidae)? Cities Environ. 2(4), 1-12.

Deng, H., Jim, C.Y. (2016) Spontaneous plant colonization and bird visits of tropical extensive green roof. Urban Ecosyst. 20, 1-16.

Donovan, T. M., Thompson, F. R. (2001) Modeling the ecological trap hypothesis: a habitat and demographic analysis for migrant songbirds. Ecol. Appl. 11(3), 871-882.

Dunnett, N., Kingsbury N. (2008) Planting green roofs and living walls, 2nd edition. Timber Press, Portland, OR, USA.

Emilsson, T. (2008) Vegetation development on extensive vegetated green roofs: influence of substrate composition, establishment method and species mix. Ecol. Eng. 33, 265-277.

Everaars, J., Strohbachm, M.W., Gruber, B., Dormann, C.F. (2011) Microsite conditions dominate habitat selection of the red mason bee (Osmia bicornis, Hymenoptera: Megachilidae) in an urban environment: A case study from Leipzig, Germany. Landsc. Urban Planning 103, 15-23.

Fernandez-Canero, R., Gonzalez-Redondo, P. (2010) Green roofs as a habitat for birds: A review. J. Anim. Vet. Adv. 9, 2041-2052.

Gedge, D., Kadas, G. (2005) Green roofs and biodiversity. Biologist 52, 161-169.

Getter, K.L., Rowe, D.B. (2008) Media depth influences Sedum green roof establishment. Urban Ecosyst. 11, 361-372.

Gonsalves, S.M. (2016) Green roofs and urban biodiversity: their role as invertebrate habitat and the effect of design on beetle community. Portland State University, Dissertations and Theses. Available from http://pdxscholar.library.pdx.edu/open_access etds/2997/ (accessed February 14, 2017).

Goulson, D., Lye, G.C., Darvill, B. (2008) Decline and conservation of bumble bees. Annu. Rev. Entomol. 53, 191-208.

Greenleaf, S.S., Williams, N.M., Winfree, R., Kremen, C. (2007) Bee foraging ranges and their relationship to body size. Oecologia 153, 589-596. 
Hagler, J.R., Jackson, C.G. (2001) Methods for marking insects: current techniques and future prospects. Annu. Rev. Entomol. 46, 511-543.

Hernandez, J.L., Frankie, G.W., Thorp, R.W. (2009) Ecology of urban bees: a review of current knowledge and directions for future study. Cities and the Environ. (CATE) 2, 1-15.

Hietel, E. (2016) Biodiversität begrünter Dächer. Ergebnisse eines Forschungsprojektes der Forschungsinitiative RLP. Pages 13-16 14. Internationales FBB-Gründachsymposium 2016 Tagungsband. Ditzingen, Germany.

Hui, S.C., Chan, K.L. (2011) Biodiversity assessment of green roofs for green building design. Proceedings of Joint Symposium on Integrated Building Design in the New Era of Sustainability. ASHRAE-HKC/CIBSE-HKB/HKIE-BSD. Available from https://hub.hku.hk/handle/10722 /166901 (accessed February 16, 2017).

Jones, R.A. (2002) Tecticolous invertebrates: a preliminary investigation of the invertebrate fauna on green roofs in urban London. English Nature, London.

Kadas, G. (2006) Rare invertebrates colonizing green roofs in London. Urban Habitats 4, 66-86.

Kaiser, C. (2014) Untersuchungen zu den Auswirkungen der extensiven Dachbegrünung auf lokale Biodiversität und Mikroklima. Bachelorarbeit. FH Bingen, Bingen, Germany.

Kälin, M. (2005) Wildbienen auf begrünten Dachflächen Substrate und ihre Auswirkungen auf die Wildbienenfauna. Semesterarbeit. Züricher Hochschule für Angewandte Wissenschaften ZHAW, Wädenswil, Switzerland.

Käppeli, S. (2010) Wildbienen auf begrünten Dächern Fördermöglichkeiten für gefährdete Arten? Semesterarbeit. Züricher Hochschule für Angewandte Wissenschaften ZHAW, Wädenswil, Switzerland.

Kessler, C. (2010) Wildbienen auf begrünten Dächern Fördermöglichkeiten für gefährdete Arten? Semesterarbeit. Züricher Hochschule für Angewandte Wissenschaften ZHAW, Wädenswil, Switzerland.

Köhler, M. (2006) Long-term vegetation research on two extensive green roofs in Berlin. Urban Habitats 4, 3-26.

Köhler, M. (2014) Untersuchungen zur Biodiversität begrünter Dächer. Pages 13-16 12. Internationales FBB-Gründachsymposium 2014, Tagungsband. Ditzingen, Germany.

Kratschmer, S.A. (2015) Summen auf den Dächern Wiens. Masterarbeit. Universität für Bodenkultur, Vienna, Austria.

Ksiazek, K., Fant, J., Skogen, K. (2012) An assessment of pollen limitation on Chicago green roofs. Landsc. Urban Plan. 107, 401-408.

Ksiazek, K., Tonietto, R., Ascher, J.S. (2014) Ten bee species new to green roofs in the Chicago area. Mich. Entomol. Soc. 47, 87-92.
Kuhlmann, M. (2015) Erfassung der Auswirkungen extensiver Dachbegrünung auf die lokale Abundanz und Vielfalt blütenbestäubender Insekten. Bachelorarbeit. FH Bingen, Germany.

Lundholm, J.T. (2016) Spontaneous dynamics and wild design in green roofs. Isr. J. Ecol. Evol. 62, 23-31.

MacIvor, J.S. (2016) Building height matters: nesting activity of bees and wasps on vegetated roofs. Isr. J. Ecol. Evol. 62, 88-96.

MacIvor, J.S., Lundholm, J. (2011) Insect species composition and diversity on intensive green roofs and adjacent level-ground habitats. Urban Ecosyst. 14, 225-241.

MacIvor, J.S., Ruttan, A., Salehi, B. (2015) Exotics on exotics: Pollen analysis of urban bees visiting Sedum on a green roof. Urban Ecosyst. 18, 419-430.

Madre, F., Vergnes, A., Machon, N., Clergeau, P. (2013) A comparison of 3 types of green roof as habitats for arthropods. Ecol. Eng. 57, 109-117.

Mann, G. (1994) Ökologisch-faunistische Aspekte begrünter Dächer in Abhängigkeit vom Schichtaufbau. Diplomarbeit. Universität Tübingen, Germany.

Mann, G. (1996a) Faunistische Untersuchungen von drei Dachbegrünungen in Linz. Öko-L 18, 3-14.

Mann, G. (1996b) Die Rolle begrünter Dächer in der Stadtökologie. Biol. Unserer Zeit. 26, 292-299.

Mann, G. (2005) Vorkommen von Tieren auf begrünten Hochhäusern. Dach+ Grün 3, 24-28.

Michener, C.D. (2007) Bees of the World, 2nd ed., John Hopkins University Press, Baltimore.

Moore, L.J., Kosut, M. (2013) Buzz: Urban beekeeping and the power of the bee. New York University Press, NY, USA.

Nagase, A., Nomura, M. (2014) An evaluation of one example of biotope roof in Japan: Plant development and invertebrate colonisation after 8 years. Urban For. \& Urban Greening 13, 714-724.

Oberndorfer, E., Lundholm, J., Bass, B., Coffman, R.R., Doshi, H., Dunnett, N., Gaffin, S., Köhler, M., Liu, K.K.Y., Rowe, B. (2007) Green roofs as urban ecosystems: ecological structures, functions, and services. BioScience 57, 823-833.

Riedmiller, J. (1991) Pflegeloses Pflanzendach Ökologisches Untersuchungen auf einem neu bepflanzten Flachdach. Diplomarbeit. Universität Heidelberg, Germany.

Riedmiller, J., Schneider, P. (1993) Begrünte Dächer als Sekundärlebensräume für bestimmte Tier-und Pflanzenarten. Veröffentlichungen des Projekts Angewandte Ökologie der LFU Baden-Württemberg, Karlsruhe (Veröff. PAÖ) 7, 155-162.

Schmidt, S., Schmid-Egger, C., Morinière, J., Haszprunar, G., Hebert, P.D.N. (2015) DNA barcoding largely supports 250 years of classical taxonomy: identifications for Central European bees (Hymenoptera, Apoidea partim). Mol. Ecol. Res. 15, 985-1000. 
Schneider, P., Riedmiller, J. (1992) Pflegeloses Pflanzendach: Neue Lebensräume in Städten. Nat.wiss. 79, 560-561.

Stutz, B. (2010) Green roofs are starting to sprout in American cities. Yale Environment 360. Available from http://e360.yale.edu/features/green roofs are starting to_sprout_in_american_cities (accessed February $1 \overline{6}, \overline{2017)}$.

Tabares-Velasco, P.C., Zhao, M., Peterson, N., Srebric, J., Berghage, R. (2012) Validation of predictive heat and mass transfer green roof model with extensive green roof field data. Ecol. Eng. 47, 165-173.

Takebayashi, H., Moriyama, M. (2007) Surface heat budget on green roof and high reflection roof for mitigation of urban heat island. Build. Environ. 42, 2971-2979.

Tonietto, R., Fant, J., Ascher, J., Ellis, K., Larkin, D. (2011) A comparison of bee communities of Chicago green roofs, parks and prairies. Landsc. Urban Plan. 103, 102-108.

Walker, E.A. (2016) Green roofs as urban habitat for native plant seedlings and wild bees. Saint Mary's University.
Available from http://library2.smu.ca/handle/01/26546 (accessed January 31, 2017).

Walker, T.J., Wineriter, S.A. (1981) Marking techniques for recognizing individual insects. Fla Entomol.t 64, 1829.

Westrich, P. (1990) Die Wildbienen BadenWürttembergs2., verb. Aufl. Ulmer, Stuttgart, Germany.

Williams, N.S.G., Lundholm, J., Scott MacIvor, J. (2014) FORUM: Do green roofs help urban biodiversity conservation? J. Appl. Ecol. 51, 1643-1649.

Witt, R. (2016) Populationen von Wildbienen und Wespen auf Gründächern. Stadt+Grün 03/2016, 37-42.

Zehnder, J. (2011) Wildbienen auf begrünten Dächern Fördermöglichkeiten für gefährdete Arten? Semesterarbeit. Züricher Hochschule für Angewandte Wissenschaften ZHAW, Wädenswil, Switzerland.

Zurbuchen, A., Müller, A. (2012) Wildbienenschutz - Von der Wissenschaft zur Praxis. Haupt Verlag, Bristol Stiftung Zürich, Switzerland. 